\title{
Particularities of the Farms in the Kurdistan Regional Government
}

\author{
Rezhen HARUN ${ }^{1)}$, Iulia C. MUREȘAN ${ }^{2)}$, Felix H. ARION²), Diana D. DUMITRAȘ ${ }^{2)}$ \\ 1) Department of Agricultural Extension. University of Sulaimani, Kurdistan Regional Government-Iraq. \\ 2) Department of Economic Sciences. University of Agricultural Sciences and Veterinary Medicine Cluj- \\ Napoca, Romania. \\ *) Corresponding author, e-mails: rezhen.rashid@univsul.edu.iq; iulia.muresan@usamvcluj.ro;
}

BulletinUASVM Horticulture 72(1) / 2015

Print ISSN 1843-5254, Electronic ISSN 1843-5394

DOI:10.15835/buasvmcn-hort:10507

\begin{abstract}
The present research describes the farms' characteristics from Kurdistan Regional Government. To achieve the aim of the paper during June-September 2012, 236 questionnaires were applied to the farmers from Kurdistan Regional Government (KRG). The descriptive statistics and chi-square test were used to analyze the data. The analysis was conducted for each of the three governorates of the region (Duhok, Erbil and Suleimani) and for two precipitation zones: A area with an average rain higher than $500 \mathrm{~mm} /$ year and B area with an average rain less than $500 \mathrm{mmm} /$ year. The results indicated that the average size of the farm in KRG in 2011 was around 13 hectares. In the attempt of reducing the negative impact of the water deficit on the production, the farmers from $B$ area increased their cultivated surfaces.
\end{abstract}

Keywords: agricultural land, farms, rural area

\section{INTRODUCTION}

Nowadays, most of the farms have often been branched on the basis of agro-ecological factors (such as climate, geomorphology, physical and chemical particularities). The size and the structure of the farm has a direct impact on the farm management. The management of the farm is based on the general purpose of the farm, degree of independence and size (Fresco and Westphal, 1988). Some researches and official data (MoP, 2012) approve that the agricultural land in the region has changed from a district to another during the last years.

\section{AIMS AND OBJECTIVES}

The objectives of the research were to analyze the characteristics of the farms is Kurdistan Region and to investigate if there are the differences among the three governorates, and among the two precipitation areas.

\section{MATERIALS AND METHODS}

The research area is located within the Northern part of the Federal Republic of Iraq, called Kurdistan Region (Iraqi constitution, article 62; Harun et al., 2013). The region has three governorates from North to South: Duhok, Erbil, Sulaimani. The area of the region is $42,812 \mathrm{~km}^{2}$ (MoP, 2012). To achieve the purpose of this paper, 236 questionnaires were applied to farmers from 46 villages during June and September 2012. The data were analyzed using the descriptive statistics and chi-square test. The analysis was done for each one of the three governorates, but also for the two precipitation zones: A zone (the average rain is more than $500 \mathrm{~mm} /$ year) and $B$ zone (the average rain is less than $500 \mathrm{~mm} /$ year).

\section{RESULTS AND DISCUSSIONS}

The property size of the agricultural land owned by the farmers from Kurdistan ranges from less than two hectares to more than 20 hectares. 


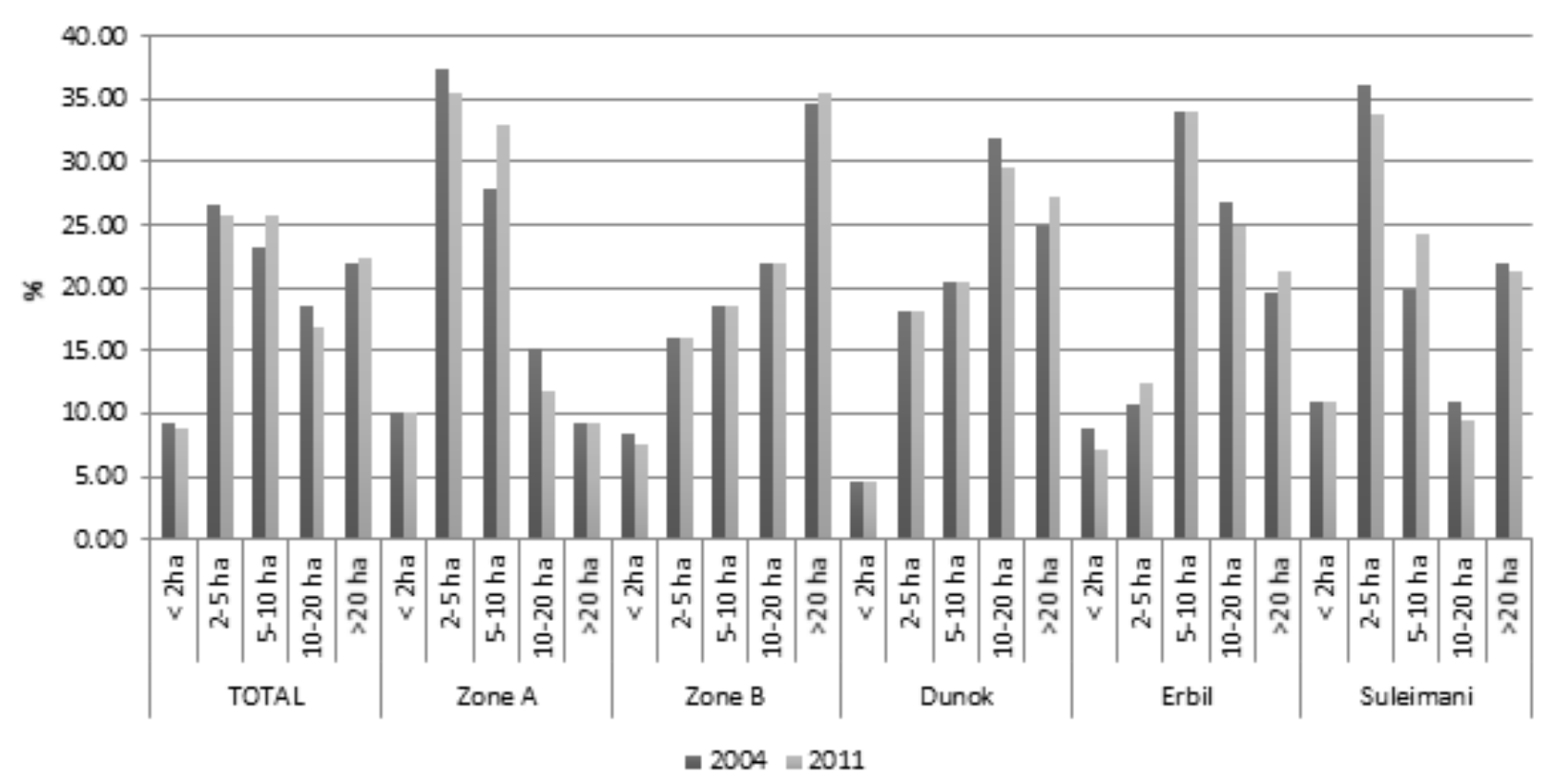

Fig. 1 Distribution of the farms by size, governorates and precipitation zones.

The average irrigated surface in 2011 was 2.21 hectares. The average surface land cultivated by a farmer in zone B is two times bigger than the average surface cultivated by a farmer in zone A. This high difference between the two zones can be an effect of the deficit of precipitations, which affects the quantity and quality of the agricultural production. Most of the land surfaces are cultivated with grains, $76.37 \%$ of the total average cultivated area with an average of 10 hectares/farm. From the three governorates, in Duhok is the highest share of the average cultivated surfaces with grain $85.68 \%$, followed by Suleimani with $74.68 \%$ and Erbil with $68.55 \%$. The average surface cultivated by a farmer with grains in zone B is four times bigger than in zone $\mathrm{A}$, and represents a share of $86.91 \%$ in the total cultivated surface, but in zone A it represents only $42.17 \%$. More than $50 \%$ of the farmers owned less than 10 hectares in 2011. The same was found in Erbil (53.57\%) and Suleimani (69.12\%) (Fig. 1). In Duhok the situation is reversed, $56.82 \%$ of the farmers own more than 10 hectares, because of the private distribution of land was completely different in the past.

The null hypothesis that there are no differences between the owned agricultural land and the cultivated area was rejected, the $\chi_{\text {value }}^{2}$ (618.761) being higher than the theoretical $\chi_{0.05 ; 20}^{2}$ (31.4). The contingency coefficient (0.851) indicates a high association between the two variables. The Person's correlation coefficient
(0.915) confirms that there is a very strong and positive correlation between the two variables. Considering the characteristics of the area, can be stated that the farmers tend to cultivate the entire owned surface.

Conclusion. The research represents the first step for the analysis of the farms' particularities in the Kurdistan Region. Differences were encountered not only among the three governorates, but also between the precipitation zones. The agriculture in Kurdistan is strongly affected by precipitations. In around 92\% of the cases the precipitation is used as the main source of water for agriculture. By this way, it is absolutely impossible to have an efficient farming activity, especially in the current situation having climatic issues as drought and shortage of water. Also the absence of the irrigation network has a negative effect on the cultivated area.

\section{REFERENCES}

1. Fresco LO, Wesphal E (1988). A Hierarchical Classification of Farm Systems in the Experimental Agriculture 24:399419.

2. Harun R, Arion FH, Muresan IC (2013). Water Consumption in Rural Area: Limits of the Ethics of Water Use-Study Case of Kurdistan Region, Iraq in the The ethics of consumption, the citizen, the market and law, 499-504.

3. Ministry of Planning, (MoP), (2012). Regional Development Strategy for Kurdistan Region, KRG. 